\title{
Bacillus velezensis sp. nov., a surfactant- producing bacterium isolated from the river Vélez in Málaga, southern Spain
}

\author{
Cristina Ruiz-García, Victoria Béjar, Fernando Martínez-Checa, \\ Inmaculada Llamas and Emilia Quesada
}

Correspondence

Emilia Quesada

equesada@ugr.es

\author{
Department of Microbiology, Faculty of Pharmacy, Campus Universitario de Cartuja, University \\ of Granada, 18071 Granada, Spain
}

\begin{abstract}
Two Gram-positive, endospore-forming bacterial strains, CR- $502^{\top}$ and CR-14b, which produce surfactant molecules are described. Phenotypic tests and phylogenetic analyses showed these strains to be members of the genus Bacillus and related to the species Bacillus atrophaeus, Bacillus mojavensis, Bacillus subtilis, Bacillus vallismortis and Bacillus amyloliquefaciens, although they differ from these species in a number of phenotypic characteristics. DNA-DNA hybridization confirmed that they show less than $20 \%$ hybridization with the above-mentioned species and therefore represent a novel species of Bacillus. The DNA G $+\mathrm{C}$ content is $46.4 \mathrm{~mol} \%$ in strain CR-502 ${ }^{\top}$ and $46 \cdot 1 \mathrm{~mol} \%$ in strain CR-14b. The main fatty acids in strain CR-502 ${ }^{\top}$ are $15: 0$ anteiso $(32 \cdot 70 \%), 15: 0$ iso $(29 \cdot 86 \%)$ and $16: 0(13 \cdot 41 \%)$. The main quinone in strain CR-502 ${ }^{\top}$ is MK-7 (96.6\%). In the light of the polyphasic evidence gathered in this study, it is proposed that these strains be classified as a novel species of the genus Bacillus, with the

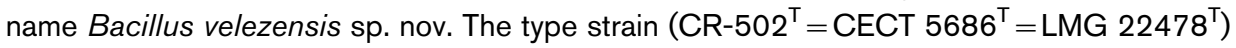
was isolated from a brackish water sample taken from the river Vélez at Torredelmar in Málaga, southern Spain.
\end{abstract}

In recent years Bacillus species have come to play an increasingly important role in applied microbiology. Nowadays some species are used in the production of enzymes, antibiotics, insecticides, surfactants and fine biochemicals, including flavour enhancers and food supplements (Banat et al., 2000; Harwood, 1989; Pinchuk et al., 2002).

We describe here a novel species of the genus Bacillus, for which we propose the name Bacillus velezensis sp. nov. The species includes two strains that were isolated during a wideranging research programme aimed at discovering novel bacterial strains capable of synthesizing new lipopeptides with surfactant and/or antimicrobial activity. To this end we sampled a number of different saline and non-saline environments during 1999 and 2000 and selected potential surfactant-producer strains by the drop-collapsing test (Bodour \& Miller-Maier, 1998; Jain et al., 1991). The two strains described here synthesize substantial yields of lipopeptides related to the surfactin family, the most active biosurfactant group reported to date. These products, which

Published online ahead of print on 30 July 2004 as DOI 10.1099/ ijs.0.63310-0.

The GenBank/EMBL/DDBJ accession numbers for the 16S rRNA gene sequences of strains CR- $502^{\top}$ and $\mathrm{CR}-14 \mathrm{~b}$ are AY603658 and AY608741 respectively. are currently being studied, also appear to exert antimicrobial activity.

Strain CR-14b was found in a sample taken at the mouth of the river Vélez at Torredelmar in the province of Málaga (southern Spain) in April 1999. Strain CR-502 ${ }^{\mathrm{T}}$ was isolated from a sample taken from the same river mouth in October 2000. The isolation medium was MY (Moraine \& Rogovin, 1966) supplemented with $7 \cdot 5 \%$ w/v salts (Rodríguez-Valera et al., 1981). Both strains grew best on tryptic soy agar (TSA) and were therefore kept and routinely grown on this medium at $32{ }^{\circ} \mathrm{C}$.

Strains CR-502 $2^{\mathrm{T}}$ and CR-14b were phenotypically analysed together with type strains of the most closely related Bacillus species and other endospore-forming bacteria according to the methods described by Claus \& Berkeley (1986), Cowan \& Steel (1994), Harwood (1989) and Logan \& Berkeley (1984). According to Nakamura et al. (1999) in their original description of the subspecies Bacillus subtilis subsp. spizizenii, the morphological, physiological and biochemical characteristics are the same as those of Bacillus subtilis subsp. subtilis, although there is a phenotypic difference between the subspecies in their cell-wall constituents. For this reason we only deemed it necessary to include in our study one of the two subspecies, $B$. subtilis subsp. subtilis. We carried out 122 phenotypic tests, 


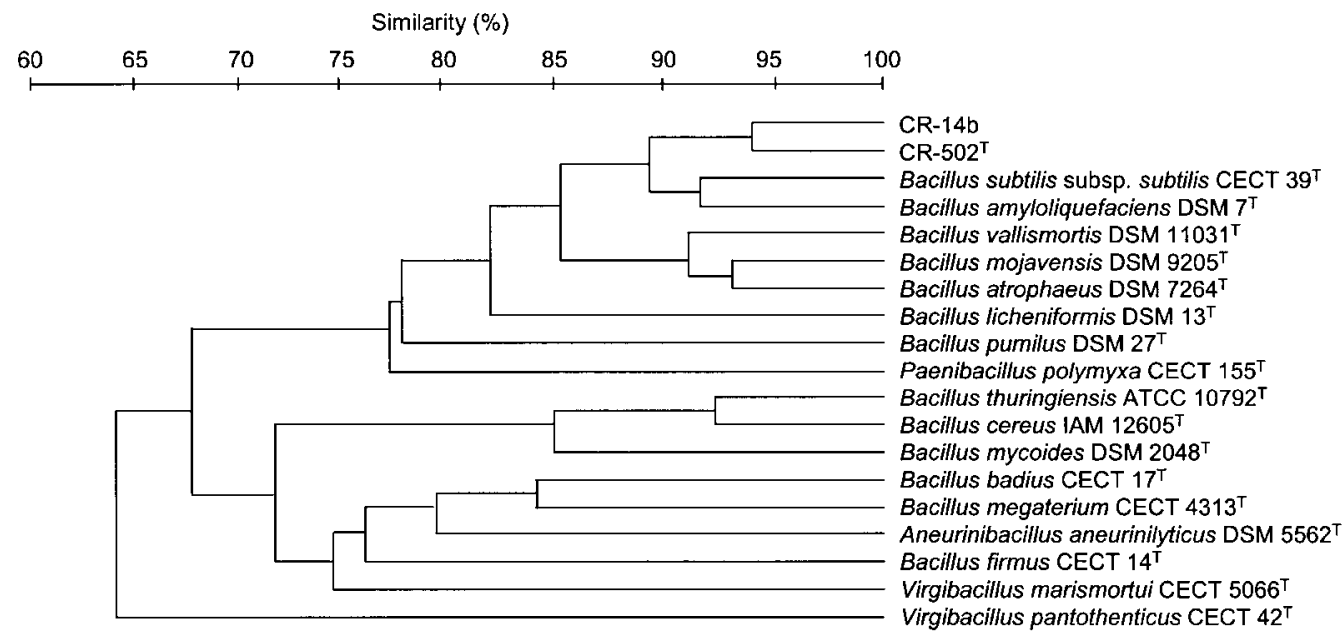

Fig. 1. Dendrogram based on phenotypic data. The simple-matching $\left(S_{S M}\right)$ coefficient and UPGMA were used.

including both API 20E and API 50 CHB (bioMérieux), the results of which appear in the species description. Morphology and the presence of flagella and endospores in strain CR $-502^{\mathrm{T}}$ were studied by transmission and scanning electron microscopy according to the methods described by Bouchotroch et al. (2001).

Differential phenotypic characteristics (92 tests) were chosen to carry out a cluster analysis using the simple-matching coefficient $\left(S_{S M}\right)$ (Sokal \& Michener, 1958) and UPGMA (Sneath \& Sokal, 1973). Computer analysis was undertaken with the TAXAN program (Information Resources Group, Maryland Biotechnology Institute, University of Maryland,
College Park, MD 20742, USA). The estimated test error (Sneath \& Johnson, 1972) was no more than $3 \%$ in any of the tests. No test was found to be so irreproducible (test variance $\geqslant 0 \cdot 2$ ) as to be excluded from the analysis. As can be seen in Fig. 1, the two strains grouped between themselves at a $94 \%$ similarity level and shared the highest similarity (about $90 \%$ ) with the cluster formed by B. subtilis subsp. subtilis and Bacillus amyloliquefaciens. Table 1 shows the main features that distinguish $B$. velezensis from other phenotypically and phylogenetically related taxa. The two novel strains are characterized by their capacity to produce acids from glycogen, lactose, methyl $\alpha$-D-glycoside and Draffinose but not from D-turanose. They do not hydrolyse

Table 1. Characteristics which distinguish Bacillus velezensis sp. nov. from other related species of Bacillus

1, B. velezensis sp. nov. CR $-502^{\mathrm{T}}$; 2, B. subtilis subsp. subtilis CECT $39^{\mathrm{T}} ; 3$, B. atrophaeus DSM $7264^{\mathrm{T}}$; 4, B. mojavensis DSM $9205^{\mathrm{T}}$; 5 , B. vallismortis DSM $11031^{\mathrm{T}} ; 6$, B. amyloliquefaciens DSM $7^{\mathrm{T}}$. Data from this study and from Nakamura (1989), Priest et al. (1987) and Roberts et al. (1994, 1996). ND, Not determined.

\begin{tabular}{|c|c|c|c|c|c|c|}
\hline Characteristic & 1 & 2 & 3 & 4 & 5 & 6 \\
\hline Pigmentation & Creamy white & Creamy white & Creamy white & Creamy white & Dark brown & Creamy white \\
\hline Oxidase & + & + & - & + & + & + \\
\hline \multicolumn{7}{|l|}{ Acid in API system from: } \\
\hline Glycogen & + & - & - & - & - & ND \\
\hline Lactose & + & - & - & - & - & + \\
\hline Melibiose & - & + & - & - & - & + \\
\hline Methyl $\alpha$-D-glycoside & + & + & - & - & - & + \\
\hline D-Raffinose & + & + & - & + & - & + \\
\hline D-Turanose & - & + & - & - & - & + \\
\hline \multicolumn{7}{|l|}{ Hydrolysis of: } \\
\hline Tween 20 & - & + & + & + & + & + \\
\hline Tween 80 & - & + & + & + & + & ND \\
\hline DNA & - & + & + & + & + & - \\
\hline Arginine dihydrolase & - & + & - & - & - & - \\
\hline ONPG & + & + & + & + & + & - \\
\hline
\end{tabular}


DNA, Tween 20 or Tween 80 . They produce $O$-nitrophenyl $\beta$-D-galactopyranoside (ONPG) but not arginine dihydrolase.

DNA was purified using the method of Marmur (1961). The $\mathrm{G}+\mathrm{C}$ content was determined from the midpoint value $\left(T_{\mathrm{m}}\right)$ of the thermal denaturation profile (Marmur \& Doty, 1962) obtained at $260 \mathrm{~nm}$ with a Perkin-Elmer UVVis Lambda3B spectrophotometer programmed for temperature increases of $1.0^{\circ} \mathrm{C} \mathrm{min}^{-1}$. $T_{\mathrm{m}}$ was determined by the graphic method described by Ferragut \& Leclerc (1976) and the $\mathrm{G}+\mathrm{C}$ content was calculated from this temperature using the equation of Owen \& Hill (1979). The $T_{\mathrm{m}}$ value of the reference DNA from Escherichia coli NCTC $9001^{\mathrm{T}}$ was taken to be $74.6{ }^{\circ} \mathrm{C}$ in $0.1 \times$ SSC (Owen \& Pitcher, 1985). The $\mathrm{G}+\mathrm{C}$ content of the two strains was $46 \cdot 4 \mathrm{~mol} \%$ for strain CR- $502^{\mathrm{T}}$ and $46 \cdot 1 \mathrm{~mol} \%$ for strain CR-14b. These $\mathrm{G}+\mathrm{C}$ values fall within the wide range of $41 \cdot 5-47 \cdot 5 \mathrm{~mol} \%$ accepted for B. subtilis (Claus \& Berkeley, 1986; Harwood, 1989).

The 16S rRNA genes were amplified by PCR using standard protocols (Saiki et al., 1988). The forward primer, 16F27 (5'-AGAGTTTGATCATGGCTCAG-3'), annealed at positions 8-27 and the reverse primer, 16R1488 (5'-CGGTTACCTTGTTAGGACTTCACC-3') (both from Pharmacia), annealed at the complement of positions 1511-1488 (E. coli numbering according to Brosius et al., 1978). We also used an intermediate primer designed by us, 5'-CGGATCGTAAAGCTCTGTTG-3'. This primer annealed at positions 401-421. The PCR products were purified using the Qiaquick spin-gel extraction kit (Qiagen). Direct sequence determinations of PCR-amplified DNAs were carried out with the ABI PRISM dye-terminator, cycle-sequencing, ready-reaction kit (Perkin-Elmer) and an ABI PRISM 377 sequencer (Perkin-Elmer) according to the manufacturer's instructions. The sequences obtained were compared to reference 16S rRNA gene sequences available in the GenBank and EMBL databases obtained from the National Center of Biotechnology Information database using the BLAST search. Phylogenetic analysis was performed using MEGA version 2.1 (Kumar et al., 2001) after multiple alignments of data by CLUSTAL X (Thompson et al., 1997). Distances and clustering were determined with the neighbourjoining and maximum-parsimony methods. The stability of clusters was ascertained by bootstrap analysis (1000 replications). The phylogenetic tree, constructed using the neighbour-joining method, is shown in Fig. 2. The maximum-parsimony algorithm gave a similar result (data not shown). The sequences of strains CR- $502^{\mathrm{T}}$ and CR-14b formed a phylogenetic branch with the species with which they also showed the highest phenotypic similarity. The highest similarity values between our strains and these species were $99 \%$ (B. subtilis subsp. subtilis, B. amyloliquefaciens and Bacillus vallismortis) and $98 \%$ (Bacillus mojavensis and Bacillus atrophaeus).

DNA-DNA hybridization was conducted following the methods of Lind \& Ursing (1986) with the modifications of Ziemke et al. (1998) and Bouchotroch et al. (2001). Strain

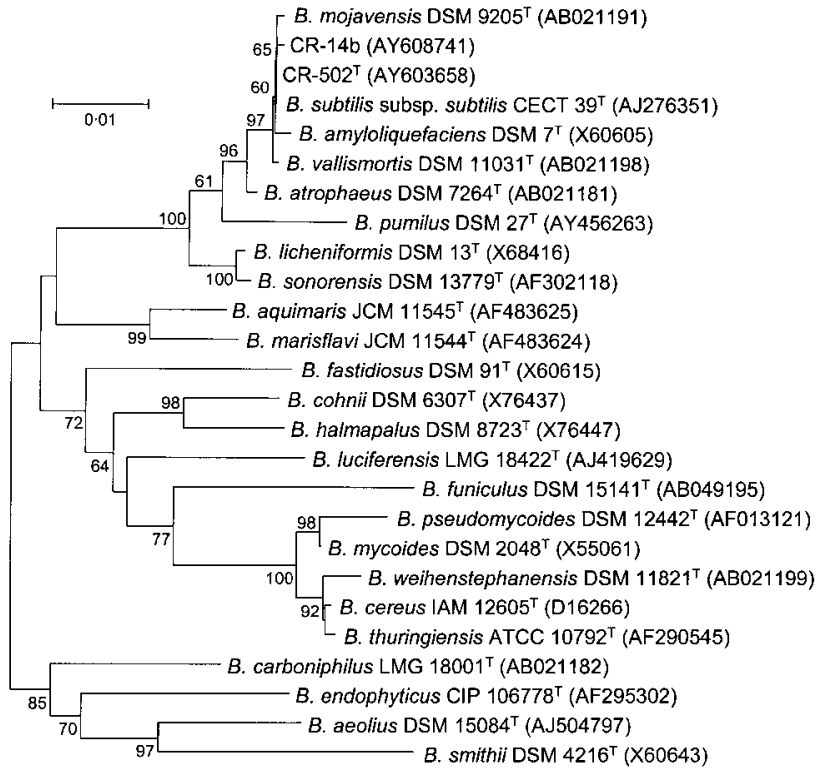

Fig. 2. Phylogenetic relationships between the two strains of Bacillus velezensis sp. nov. and other Bacillus species. The tree was constructed using the neighbour-joining algorithm. Only bootstrap values above $60 \%$ are shown (1000 replications). Bar, $1 \%$ estimated sequence divergence.

CR- $502^{\mathrm{T}}$ was not related to the other type strains of related species, showing less than $20 \%$ hybridization with them (Table 2).

Fatty-acid analysis of strain CR-502 ${ }^{\mathrm{T}}$ was undertaken by the analytical services of Microbial Identification Systems (Williston, VT 05495, USA), using the MID/Hewlett Packard Microbial Identification System (MIS), which relies upon high-resolution GC to obtain the fatty-acid profile. The results of their chemotaxonomic analyses are

Table 2. $\mathrm{G}+\mathrm{C}$ content and DNA-DNA hybridization between strain $\mathrm{CR}-502^{\top}$ and other related taxa

Values are mean results of at least three independent determinations, which generally did not differ by more than $5 \%$. Data from this study and from Claus \& Berkeley (1986), Roberts et al. (1994, 1996), Nakamura (1989) and Priest et al. (1987).

\begin{tabular}{|c|c|c|}
\hline Strain & $\begin{array}{c}\text { Hybridization } \\
\text { with CR-502 }^{\mathrm{T}}(\%)\end{array}$ & $\begin{array}{c}\mathrm{G}+\mathrm{C} \text { content } \\
(\mathrm{mol} \%)\end{array}$ \\
\hline $\mathrm{CR}-502^{\mathrm{T}}$ & 100 & $46 \cdot 4$ \\
\hline CR-14b & $81 \cdot 9$ & $46 \cdot 1$ \\
\hline $\begin{array}{l}\text { B. subtilis subsp. subtilis } \\
\text { CECT } 39^{\mathrm{T}}\end{array}$ & $13 \cdot 3$ & $41 \cdot 5-47 \cdot 5$ \\
\hline B. mojavensis DSM $9205^{\mathrm{T}}$ & $8 \cdot 3$ & 43 \\
\hline B. atrophaeus DSM $7264^{\mathrm{T}}$ & $9 \cdot 3$ & $41-43$ \\
\hline B. vallismortis DSM $11031^{\mathrm{T}}$ & $9 \cdot 3$ & 43 \\
\hline B. amyloliquefaciens DSM $7^{\mathrm{T}}$ & $18 \cdot 6$ & $43-44 \cdot 35$ \\
\hline
\end{tabular}


Table 3. Main differences in cellular fatty-acid composition (\%) between B. velezensis sp. nov. CR- $502^{\top}$ and type strains of other related species of Bacillus

Strains: 1, B. velezensis sp. nov. CR-502 ${ }^{\mathrm{T}}$; 2, B. mojavensis NRRL B- $14698^{\mathrm{T}}$; 3, B. subtilis NRRL NRS$744^{\mathrm{T}} ; 4$, B. amyloliquefaciens ATCC $23350^{\mathrm{T}} ; 5$, B. atrophaeus NRRL NRS-213 ${ }^{\mathrm{T}} ; 6$, B. licheniformis ATCC $14580^{\mathrm{T}} ; 7$, B. vallismortis NRRL B-14890 ${ }^{\mathrm{T}}$. Data from this study and Roberts et al. $(1994,1996)$. -, Not detected.

\begin{tabular}{|lccccccc|}
\hline Fatty acid & $\mathbf{1}$ & $\mathbf{2}$ & $\mathbf{3}$ & $\mathbf{4}$ & $\mathbf{5}$ & $\mathbf{6}$ & $\mathbf{7}$ \\
\hline $13: 0$ iso & $0 \cdot 87$ & - & - & - & - & - & - \\
$14: 0$ & $2 \cdot 96$ & - & - & - & - & - & - \\
$14: 0$ iso & $1 \cdot 08$ & $0 \cdot 98$ & $1 \cdot 13$ & $2 \cdot 46$ & $1 \cdot 44$ & $1 \cdot 31$ & - \\
$15: 0$ anteiso & $32 \cdot 70$ & $42 \cdot 51$ & $40 \cdot 19$ & $36 \cdot 48$ & $51 \cdot 36$ & $37 \cdot 75$ & $37 \cdot 5$ \\
$15: 0$ iso & $29 \cdot 86$ & $22 \cdot 33$ & $29 \cdot 27$ & $30 \cdot 50$ & $15 \cdot 02$ & $28 \cdot 87$ & $24 \cdot 60$ \\
$16: 0$ & $13 \cdot 41$ & $2 \cdot 05$ & $3 \cdot 14$ & $4 \cdot 52$ & $1 \cdot 99$ & $3 \cdot 91$ & $2 \cdot 71$ \\
$16: 0$ iso & $1 \cdot 31$ & $2 \cdot 56$ & $2 \cdot 36$ & $4 \cdot 40$ & $3 \cdot 10$ & $4 \cdot 42$ & $4 \cdot 06$ \\
$16: 1 \omega 5 c$ & - & $1 \cdot 74$ & $1 \cdot 52$ & $2 \cdot 14$ & $1 \cdot 72$ & $1 \cdot 53$ & $0 \cdot 64$ \\
$16: 1 \omega 9 c$ & - & $0 \cdot 69$ & $0 \cdot 23$ & $0 \cdot 62$ & $1 \cdot 16$ & $0 \cdot 91$ & $0 \cdot 45$ \\
$16: 1 \omega 11 c$ & $4 \cdot 42$ & - & - & - & - & - & - \\
$17: 0$ iso & $7 \cdot 67$ & $8 \cdot 92$ & $9 \cdot 59$ & $9 \cdot 01$ & $4 \cdot 97$ & $6 \cdot 99$ & $14 \cdot 43$ \\
$17: 0$ anteiso & $4 \cdot 27$ & $12 \cdot 53$ & $9 \cdot 38$ & $7 \cdot 06$ & $14 \cdot 83$ & $11 \cdot 30$ & $12 \cdot 07$ \\
$17: 1 \omega 7 c$ iso & - & $3 \cdot 45$ & $1 \cdot 72$ & $1 \cdot 67$ & $1 \cdot 99$ & $1 \cdot 23$ & $1 \cdot 55$ \\
$17: 1 \omega 10 c$ iso & $1 \cdot 44$ & - & - & - & - & - & - \\
\hline
\end{tabular}

given in the species description and in Table 3. Strain CR $-502^{\mathrm{T}}$ showed a specific fatty-acid profile characterized mainly by its high 16:0 fatty-acid content and the presence of $16: 1 \omega 11 c, 13: 0$ iso, $14: 0$ and $17: 1 \omega 10 c$ iso.

Quinones were identified by HPLC at the DSMZ (Deutsche Sammlung von Mikroorganismen und Zellkulturen $\mathrm{GmbH}$ ). As in other Bacillus strains, the main quinone in strain CR$502^{\mathrm{T}}$ was menaquinone with seven isoprene units, MK-7 $(96 \cdot 6 \%)$, plus a minor proportion of MK-6 (3.4\%).

Accordingly, on the basis of differences in phenotypic and chemotaxonomic characteristics and genetic distinctiveness, strains $\mathrm{CR}-502^{\mathrm{T}}$ and $\mathrm{CR}-14 \mathrm{~b}$ should be recognized as representing a novel species of the genus Bacillus, for which we propose the name Bacillus velezensis.

\section{Description of Bacillus velezensis sp. nov.}

Bacillus velezensis (vel.e.zen'sis. N.L. adj. masc. velezensis pertaining to Vélez, named thus for being first isolated from the river Vélez in Málaga, southern Spain).

The cells are Gram-positive rods, $0 \cdot 5 \times 1 \cdot 5-3 \cdot 5 \mu \mathrm{m}$, occurring both singly and in pairs and occasionally in short chains. Endospores are ellipsoidal and lie in paracentral or subterminal positions in non-swollen sporangia. They do not contain parasporal crystals or accumulate poly- $\beta$ hydroxybutyric acid. They are motile by peritrichous flagella. On TSA medium the bacteria grow in creamywhite, rough colonies with slightly irregular edges. In liquid TSB medium a thin film is formed at the surface whilst the rest of the medium is uniformly cloudy, showing no strands or clumps. They are capable of growing in
$\mathrm{NaCl}$ concentrations of up to $12 \%$ w/v. They grow within the temperature range of 15 to $45^{\circ} \mathrm{C}$ and at $\mathrm{pH}$ values of between 5 and 10. They are chemo-organotrophic. Catalase and oxidase are produced. Their metabolism is respiratory, with oxygen as terminal electron acceptor. They do not grow in anaerobiosis in the presence of nitrate or fumarate. They produce acids (without gas) from aesculin, amygdalin, L-arabinose, arbutin, cellobiose, D-fructose, glycerol, Dglucose, glycogen, inositol, lactose, maltose, mannitol, D-mannose, methyl $\alpha$-D-glycoside, D-raffinose, D-ribose, salicin, sorbitol, sucrose, trehalose and D-xylose. They do not produce acids from adonitol, D-arabinose, D-arabitol, L-arabitol, 2- or 5-ketogluconate, dulcitol, erythritol, Dor L-fucose, galactose, $\beta$-gentiobiose, gluconate, inulin, D-lyxose, D-melezitose, melibiose, methyl $\alpha$-D-mannoside, methyl $\beta$-D-xyloside, $N$-acetylglucosamine, rhamnose, Lsorbose, D-tagatose, D-turanose, xylitol or L-xylose. They reduce nitrate and produce $\mathrm{H}_{2} \mathrm{~S}$ from L-cysteine. VoguesProskauer and ONPG are positive. They hydrolyse blood, starch, gelatin and casein. They grow in media without yeast extract. Indol, lysine decarboxylase, ornithine decarboxylase, urease, arginine dihydrolase, tryptophan deaminase, phenylalanine deaminase and growth on lysozyme $(0 \cdot 001 \%$, $\mathrm{w} / \mathrm{v}$ ) are negative. They do not hydrolyse Tween 20 , Tween 80 , DNA or tyrosine. They are susceptible to amoxicillin $(25 \mu \mathrm{g})$, amoxicillin/clavulanic acid $(30 \mu \mathrm{g})$, cephalotin $(30 \mu \mathrm{g})$, chloramphenicol $(30 \mu \mathrm{g})$, colistin $(10 \mu \mathrm{g})$, doxycycline $(30 \mu \mathrm{g})$, erythromycin $(15 \mu \mathrm{g})$, kanamycin $(30 \mu \mathrm{g})$, nalidixic acid $(30 \mu \mathrm{g})$, nitrofurantoin $(300 \mu \mathrm{g})$, norfloxacin $(5 \mu \mathrm{g})$, novobiocin $(30 \mu \mathrm{g})$, rifampicin $(30 \mu \mathrm{g})$, trimetroprim/sulfamethoxazole $(1 \cdot 25 / 23 \cdot 75 \mu \mathrm{g})$ and vancomycin $(30 \mu \mathrm{g})$. They are resistant to aztreonam $(30 \mu \mathrm{g})$. The DNA G $+\mathrm{C}$ content is $46 \cdot 1-46 \cdot 4 \mathrm{~mol} \%$ ( $T_{\mathrm{m}}$ method). 
The type strain is strain CR $-502^{\mathrm{T}}\left(=\mathrm{CECT} 5687^{\mathrm{T}}=\mathrm{LMG}\right.$ $22478^{\mathrm{T}}$ ), which was isolated from a brackish water sample taken at the mouth of the river Vélez at Torredelmar, Málaga, southern Spain. The description of the type strain is the same as that of the species. Additionally, this strain is able to produce acids from starch and sucrose and produce dihydroxyacetone. It is resistant to ceftazidime $(30 \mu \mathrm{g})$. Contrary to strain CR-14b, the type strain does not use citrate as sole source of carbon and energy and does not produce lecithinase. The major fatty acids are 15:0 anteiso $(32 \cdot 70 \%), 15: 0$ iso $(29 \cdot 86 \%)$ and $16: 0(13 \cdot 41 \%)$. The main quinone is MK-7 $(96 \cdot 6 \%)$. Its DNA G $+\mathrm{C}$ content is $46 \cdot 4 \mathrm{~mol} \%$ ( $T_{\mathrm{m}}$ method).

\section{Acknowledgements}

This research was supported by grants from the Dirección General de Investigación Científica y Técnica (BOS2003-00498) and from the Plan Andaluz de Investigación, Spain. Thanks go to our colleague Dr J. Trout for revising our English text and for advice on the Latin nomenclature.

\section{References}

Banat, J. M., Makkar, R. S. \& Cameotra, S. S. (2000). Potential commercial applications of microbial surfactants. Appl Microbiol Biotechnol 53, 495-508.

Bodour, A. A. \& Miller-Maier, R. M. (1998). Application of a modified drop-collapse technique for surfactant quantitation and screening of biosurfactant-producing microorganisms. J Microbiol Methods 32, 273-280.

Bouchotroch, S., Quesada, E., Del Moral, A., Llamas, I. \& Béjar, V. (2001). Halomonas maura sp. nov., a novel, moderately halophilic, exopolysaccharide-producing bacterium. Int J Syst Evol Microbiol 51, 1625-1632.

Brosius, J., Palmer, M. L., Kennedy, P. J. \& Noller, H. F. (1978). Complete nucleotide sequence of a $16 \mathrm{~S}$ ribosomal RNA gene from Escherichia coli. Proc Natl Acad Sci U S A 75, 4801-4805.

Claus, D. \& Berkeley, R. C. W. (1986). Genus Bacillus Cohn 1872. In Bergey's Manual of Systematic Bacteriology, vol. 2, pp. 1105-1139. Edited by P. H. A. Sneath, N. S. Mair, M. E. Sharpe \& J. G. Holt. Baltimore: Williams \& Wilkins.

Cowan, S. T. \& Steel, K. J. (1994). Manual for the Identification of Medical Bacteria. Cambridge: Cambridge University Press.

Ferragut, C. \& Leclerc, H. (1976). Étude comparative des méthodes de détermination du Tm de l'ADN bactérien. Ann Microbiol 127, 223-235 (in French).

Harwood, C. R. (1989). Bacillus. Biotechnology Handbooks. 2. Edited by T. Atkinson \& R. F. Sherwood. New York \& London: Plenum.

Jain, D. K., Collins-Thomson, D. L., Lee, H. \& Trevors, J. T. (1991). A drop-collapsing test for screening surfactant-producing microorganisms. J Microbiol Methods 13, 271-279.

Kumar, S., Tamura, K., Jakobsen, I. B. \& Nei, M. (2001). MEGA2: molecular evolutionary genetics analysis software. Bioinformatics $\mathbf{1 7}$, 1244-1245.

Lind, E. \& Ursing, J. (1986). Clinical strains of Enterobacter agglomerans (synonyms, Erwinia herbicola, Erwinia milletiae) identified by DNA-DNA hybridization. Acta Pathol Microbiol Immunol Scand Sect B 94, 205-213.

Logan, N. A. \& Berkeley, R. C. W. (1984). Identification of Bacillus strains using the API system. J Gen Microbiol 130, 1871-1882.
Marmur, J. (1961). A procedure for the isolation of deoxyribonucleic acid from micro-organisms. J Mol Biol 3, 208-212.

Marmur, J. \& Doty, P. (1962). Determination of the base composition of deoxyribonucleic acid from its thermal denaturation temperature. J Mol Biol 5, 109-118.

Moraine, R. A. \& Rogovin, P. (1966). Kinetics of polysaccharide B-1459 fermentation. Biotechnol Bioengin 8, 511-524.

Nakamura, L. K. (1989). Taxonomic relationship of black-pigmented Bacillus subtilis strains and a proposal for Bacillus atrophaeus sp. nov. Int J Syst Bacteriol 39, 295-300.

Nakamura, L. K., Roberts, M. S. \& Cohan, F. M. (1999). Relationship of Bacillus subtilis clades associated with strains 168 and W23: a proposal for Bacillus subtilis subsp. subtilis subsp. nov. and Bacillus subtilis subsp. spizizenii subsp. nov. Int J Syst Bacteriol 49, 1211-1215.

Owen, R. J. \& Hill, L. R. (1979). The estimation of base compositions, base pairing and genome size of bacterial deoxyribonucleic acids. In Identification Methods for Microbiologists, 2nd edn, pp. 277-296. Edited by F. A. Skinner \& D. W. Lovelock. London: Academic Press.

Owen, R. J. \& Pitcher, D. (1985). Current methods for estimating DNA composition and levels of DNA-DNA hybridization. In Chemical Methods in Bacterial Systematics, pp. 67-93. Edited by M. Goodfellow \& D. E. Minnikin. London: Academic Press.

Pinchuk, I. V., Bressollier, P., Sorokulova, I. B., Verneuil, B. \& Urdaci, M. (2002). Amicoumacin antibiotic production and genetic diversity of Bacillus subtilis strains isolated from different habitats. Res Microbiol 153, 269-276.

Priest, F. G., Goodfellow, M., Shute, L. A. \& Berkeley, R. C. W. (1987). Bacillus amyloliquefaciens sp. nov., nom. rev. Int J Syst Bacteriol 37, 69-71.

Roberts, M. S., Nakamura, L. K. \& Cohan, F. M. (1994). Bacillus mojavensis sp. nov., distinguishable from Bacillus subtilis by sexual isolation, divergence in DNA sequence and differences in fatty acid composition. Int J Syst Bacteriol 44, 256-264.

Roberts, M. S., Nakamura, L. K. \& Cohan, F. M. (1996). Bacillus vallismortis sp. nov., a close relative of Bacillus subtilis isolated from soil in Death Valley, California. Int J Syst Bacteriol 46, 470-475.

Rodríguez-Valera, F., Ruiz-Berraquero, F. \& Ramos-Cormenzana, A. (1981). Characteristics of the heterotropic bacterial populations in hypersaline environments of different salt concentration. Microbiol Ecol 7, 235-243.

Saiki, R. K., Gelfand, D. H., Stoffel, S., Scharf, S. J., Higuchi, R., Horn, G. T., Mullis, K. B. \& Erlich, H. A. (1988). Primer-directed enzymatic amplification of DNA with thermostable DNA polymerase. Science 239, 487-491.

Sneath, P. H. A. \& Johnson, R. (1972). The influence on numerical taxonomic similarities of errors in microbiological test. J Gen Microbiol 72, 377-392.

Sneath, P. H. A. \& Sokal, R. R. (1973). Numerical Taxonomy. The Principles and Practice of Numerical Classification. San Francisco: W. H. Freeman.

Sokal, R. R. \& Michener, C. D. (1958). A statistical method for evaluating systematic relationships. Univ Kansas Sci Bull 38, 1409-1438.

Thompson, J. D., Gibson, T. J., Plewniak, F., Jeanmougin, F. \& Higgins, D. G. (1997). The CLUSTAL_X windows interface: flexible strategies for multiple sequence alignment aided by quality analysis tools. Nucleic Acids Res 25, 4876-4882.

Ziemke, F., Höfle, M. G., Lalucat, J. \& Rosello-Mora, R. (1998). Reclassification of Shewanella putrefaciens Owen's group II as Shewanella baltica sp. nov. Int J Syst Bacteriol 48, 179-186. 